\title{
Speech Strategies and Self-Presentation Techniques of Candidates for the Head of the City Administration (as exemplified by the 2010 election campaign in Nizhny Novgorod, Russia)
}

\author{
Rimma A. Ivanova* \\ National Research University \\ Higher School of Economics \\ 25/12 Bolshaya Pecherskaya Str., \\ Nizhny Novgorod, 603155, Russia
}

Received 19.02.2016, received in revised form 26.04.2016, accepted 15.07.2016

The article concerns the research of modern Russian regional politicians' speech portraits. The subject of research is a pragmatic-linguistic unit understood as a minimal, phonetically integral and logically complete speech segment. In the report the author emphasizes speech traits and qualities typical for both experienced and popular politicians and political start-uppers. The research shows different speech portraits of candidates for the head of the city administration of Nizhny Novgorod (Russia), their various communicative images. The candidates' speech strategies prove to be the only possible variant for elective position assignment. The language analysis of the pre-election campaign speeches demonstrates the candidates to use two kinds of speech strategies: positive and negative. By the forming of the pre-election campaign speeches strengths the neutral adjectives with some additional positive and negative connotations are used. The weaknesses most reflect fracturing behavior, which is more characteristic for animals.

Keywords: political discourse, speech portrait, politician's communicative image, speech strategies, self-presentation techniques.

DOI: 10.17516/1997-1370-2016-9-9-2082-2091.

Research area: philology.

\section{Introduction}

The article highlights the main communicative properties of modern political speeches of regional officials and a complex of linguistic means contributing to a speech portrait of an individual.

The inevitable interest to the political elite of countries, regions and districts has grown significantly in the recent dozens of years: many politicians hold power for quite a long time, and their personalities, characters and personal life are under scrutiny by the public. This circumstance is a reason for many investigations in various aspects of activities of a politician of any standing as well as in "his/her needs, motifs,

(C) Siberian Federal University. All rights reserved

* Corresponding author E-mail address: holzmann2009@yandex.ru 
goals, intentions and expectations, his practices and communicative actions, communicative situations in which (s)he acts as the initiator and leader or, otherwise, as a secondary performer" (Aristov, Susov 1999, 5).

Due to the relative democratization of the social life in modern Russia, political communication has become a subject of investigation by many Russian and foreign linguists. The list includes works of A. Wierzbicka (Wierzbicka 1993), P. Chilton (Chilton 1994), A. Baranov (Baranov 1997), E. Borisova (Borisova 1998), R. Wodak, M. Sedlak (Wodak, Sedlak 2000), O. Vorobieva (Vorobieva 2000), R. Dalton, H.-D. Klingemann (Dalton, Klingemann 2007), M. Dementieva (Dementieva 2009), etc.

It is noteworthy that the major portion of modern research in the field uses speeches of state level politicians such as Vladimir Putin, Boris Yeltsin, Dmitri Medvedev, Vladimir Zhirinovsky, Gennady Zyuganov as a source of information while social and speech portrait of regional leaders is not analyzed. The research has been conducted on the material of current political speeches. This report focuses on peculiarities of speech portraits created within the propaganda genre in the course of election campaign.

Many Russian linguists (S. Leorda, E. Osetrova, T. Tarasenko, etc.) stress the importance of speech portrait in creation of a politician's communicative image. In my survey I analyze the concept of speech portrait using Tarasenko's definition according to which a speech portrait is "a combination of linguistic and speech characteristics of a communicating individual or a social group in a certain period of their existence" (Tarasenko 2007, 8).

Therefore, thepresented researchis topical for its detailed investigation of speech characteristics and public speech peculiarities during election campaign as well as for analysis of conditions in which the communicative image of the regional political elite is created. An important objective is to make an individual speech portrait of each politician with due account of the characteristic features of his/her campaign.

Politicking speeches of eight politicians who ran for the office of the head of the Administration of Nizhny Novgorod are used as the object of research. The list of politicians includes:

- Vladimir Bulanov, born 1968, General Director of Concern Termal CJSC;

- Victor Voroshilov, born 1971, General Director of BAGEM LLC.;

- Vladimir Dyakov, born 1968, General Director of Trackline LLC.;

- Vitaly Zaitsev, born 1978, Finance Director of Krupny Stroitelny Biznes (Large Construction Business) LLC.;

- Andrey Ivanov, born 1966, DirectorCorporate Development, Decima Ball-Bearing Works JSC.;

- Oleg Kondrashov, born 1967, General Director of Nizhny Novgorod Power Sales Company JSC.;

- Alexander Kuznetsov, born 1959, General Director of Electronics Chain LLC.;

- Vladimir Pinchevich, born 1958, General Director of Kater Plast LLC.

The subject of research is a pragmaticlinguistic unit understood as a minimal, phonetically integral and logically complete speech segment.

The investigation is based on the following hypothesis: a social group of political leaders is a community of people who have speech portraits of their own and who can win supporters among the electorate or, otherwise, let them down using certain speech strategies in their politicking activity.

The goal is to discover the principal features of politicians' speech portraits and to analyze the strategies used in politicking activities by the regional political elite. 
To achieve the goal the following tasks are solved:

1) to determine the dominant features of the speech portrait of each of the politicians and to describe the linguistic means used in creation of the portrait;

2) to determine the principal speech strategies used during the election campaign.

The material studied includes public speeches of the candidates, their interviews, materials of election campaigns, online materials posted in November 2009 through September 2010.

The originality of the research of speech portrait of regional politicians is due to the growing significance of social and communicative image of a modern politician since any public figure is interesting mainly as a personality, i.e. as a complex of psychoemotional, moral and intellectual features and motifs of his/her actions. A political speech is a valuable source of information about a politician since it is "an integral part of his/her character and determines rigidly the personality" (Soper 1995, 8).

\section{Analyzing speech strategies and self-presentation techniques of candidates for the head of the city administration}

Unlike in other professions, a speech in politics is a ritualized linguistic phenomenon since the political communication process can be forecast on the basis of the widely recognized triunity of the speech act:

Addresser - subject matter - recipient (addressee).

It is the political discourse where the trichotomy is realized most completely.

To analyze a speech portrait, it is reasonable to start with the description of politicians' speech peculiarities at all levels of the language, special features of their speech behavior related to their individual and professional characteristics, their histories and conditions in which they have mastered the Russian language.

In European countries a city manager is responsible for improvement of the municipal economy, effective use of the city budget, maintenance of order and providing the best living conditions.

In Russia a city manager is responsible for the municipal services too, but (s)he is also bound to solve problems of political nature, for example, to provide legal and other kind of support to the most influential part of the local elite.

The head of the city administration and the city manager are believed to be the most experienced and active citizens who are elected by majority of votes. Their primary function is to represent the city at various levels of power as well as to maintain and develop municipal services.

At the suggestion of the Governor of the Nizhny Novgorod region the city manager was vested with the major duties of the mayor in 2011 to boost the efficiency of the city government. The city manager is nominated by the City Duma, that represents interests of residents of the city districts, under a contract, while the mayor's office is only representative. The new city manager was not elected by plebiscite; he was chosen among the members of the City Duma by the deputies themselves.

It was revealed by the analysis of election speeches of the eight candidates who ran for the city manager's office that they stressed the need of the following skills and properties:

- a leading politician who is able to influence relations in the society in the interests of the city residents (V. Dyakov, A. Ivanov, O. Kondrashov, V. Pinchevich);

- the best HR manager who is capable to attract professionals to the municipal management and to coordinate the activities of the municipal officials (V. Bulanov, V. Dyakov, V. Zaitsev, 
A. Ivanov, O. Kondrashov, A. Kuznetsov, V. Pinchevich);

- a financial expert who is able to manage finance and attract investment for the municipal services, who is experienced in using budget and extrabudgetary funds (V. Bulanov, V. Voroshilov, V. Dyakov, V. Zaitsev, A. Ivanov, O. Kondrashov);

- a diplomat who is capable of negotiating and constructive compromising (V. Bulanov, V. Dyakov, O. Kondrashov, A. Kuznetsov);

- an image-maker who is able to create a positive image of the city in the eyes of prospective business partners of the region (V. Bulanov, V. Voroshilov, A. Ivanov, O. Kondrashov);

- an economist who is capable of managing the municipal services efficiently and taking responsible decisions in the field of housing and city infrastructure (V. Dyakov, V. Zaitsev, A. Ivanov, O. Kondrashov, V. Pinchevich);

- aleader who can lead people(V.Bulanov, V. Voroshilov, V. Dyakov, V. Zaitsev, A. Ivanov, O. Kondrashov, A. Kuznetsov, V. Pinchevich);

- a charismatic personality, a politician who is attractive and has exceptional personality features and strong character (V. Bulanov, V. Dyakov, V. Voroshilov, V. Pinchevich);

- an objectivist who is capable of estimating the situation and his/her actions, both good and bad, adequately (V. Bulanov, V. Voroshilov, O. Kondrashov);

- a PR manager who is capable of forming public opinion required by him but not adequate to the specific situation; for example, (s)he can withhold some information about the situation if the information can provoke undesirable reaction of the public; (s)he can mislead the public in order to ensure stability, (s)he can draw the public's attention only to a part of a problem in order to cause the desirable reaction (V. Voroshilov, V. Pinchevich);

- $a$ vendor who is capable of promoting himself or herself as well as his/her advantages so that to occupy a certain position in the society and hierarchy regardless of the degree of social and professional conformity to the position (V. Bulanov, V. Dyakov, V. Voroshilov, O. Kondrashov, V. Pinchevich);

- a wealthyperson who can present himself as a rich man regardless of the real material standing (V. Bulanov, V. Dyakov, V. Voroshilov, V. Zaitsev, O. Kondrashov, A. Kuznetsov);

- a lobbyist who has relations at the regional and federal levels established personally and in the course of the professional activity and required to lobby the interests of the city (V. Bulanov, V. Dyakov, A. Ivanov, O. Kondrashov, A. Kuznetsov);

- an actor who always plays a certain role and plays for the public regardless of his/ her artistic abilities; besides, (s)he has attractive appearance and style of behavior (V. Bulanov, V. Zaitsev, O. Kondrashov, A. Kuznetsov).

According to the survey results, each of the candidates values most of all qualities of a "leader", the "best HR manager", an "economist" and a "wealthy person".

These roles are valued by the candidates because each of them is a top manager of a large private company. The position requires a sound leadership strategy, excellent skills of recruiting personnel, ability to build financial policy of the company and to provide sophisticated production with primary and secondary resources. It is noteworthy that each of the candidates has gained the reputation of a successful entrepreneur and a competent manager of a large company. Moreover, each of them has sufficient capital required to run the campaign.

Such qualities as a "leading politician", an "objectivist", a "diplomat" and a "lobbyist" are less significant for the politicking during the campaign.

Few candidates stressed theirpartyaffiliation; moreover, some candidates consciously tried to 
avoid emphasis on their party identification. Yet, it is fair to say that the Governor of the Nizhny Novgorod region underlined that he had a special liking for Oleg Kondrashov because he is a member of United Russia party. In the campaign speeches of the candidates the most obvious positioning of himself as a leading politician was that of A. Ivanov, Director - Corporate Development, Decima Ball-Bearing Works JSC, who did not conceal his wish to become the governor of the region or a member of the State Duma in future.

Each candidate considered it to be one of the key priorities of the city manager to attract extrabudgetary investment and to solve problems of further development of the municipal services in line with the Address of Dmitri Medvedev who was the President of the Russian Federation at the time. It should be stressed that many candidates thought themselves to be objectivists but some of them are not aware of the real situation in the city or set "nonobjective" tasks without being aware that particular plans of solving many problems in the city are not sufficiently budgeted.

Almost all the candidates think it is important to lobby the interests of local manufacturers and to attract state orders to the Nizhny Novgorod region at the federal level and the level of the Volga Federal district. Some of them reveal the fact that they enjoy political support both in Moscow and in the District capital referring to specific ministries officials, State Duma deputies and members of the Council of Federation; others seem to pretend that they have this support.

It should be noted that, although many candidatesposition themselves as the "leaders", not all of them behave as "charismatic personalities". Moreover, V. Bulanov and V. Pinchevich, who are definitely charismatic personalities, failed to use this feature for their advantage.

Probably, some representatives of this social group try to be objective in estimating their own potential, and they understand that the leaders capable of managing the city economy not always think themselves to be charismatic personalities.

All candidates can be characterized as "flexible" people who are capable of taking into account objective conditions and adapting to various situations. All of them are self-confident individuals who have professional understanding of political and economic concepts, and they are optimistic about further development of the city. Such is the overall, collective portrait of a candidate running for the head of the city administration.

Of great interest is the way how the candidates presented themselves to the public. Speech communication is always influenced by the social and cultural environment, experience, needs, an attitude to the world, the system of values, etc. Speech of a human being is his/her most prominent identification characteristic and reflects personal features of a human being (Susov 1984, 3).

It is obvious that for successful selfpresentation one is expected to possess some artistic skills and ability to express himself verbally as well as the ability to conform to the image of a disciplined, orderly person who wears stylish clothes that are not fancy at the same time. In this respect A. Kuznetsov, with his joyfulness and his wish to impress the audience, outstrips his rivals. V. Bulanov turned out to be an emotive, nervous person: apparently, it took him a lot of mental energy and sanity to run the campaign, and this fact affected his public speeches.

Undoubtedly, the candidates applied a wellknown and widely used scheme of public speech that includes:

1) stating a problem;

2) asserting the problem;

3) searching for ways of solving the problem. 
In terms of composition, an election campaign speech and its verbal presentation are comprehensible for any social group.

A public speech is expected to observe certain norms, and the degree to which the norms are observed characterizes the speech culture of a politician. The norms imply, first and foremost, certain logic that makes a political speech logical. Connections between the elements of a public speech must not contradict the logical laws. Violation of the norms affects the coherence and integrity of a text and causes disorientation of the target audience, mistakes and misunderstanding.

Further survey of the speech portrait of the candidates comes down to analysis of units of various levels typical of a candidate's communicative image since "language paradigms - from phonetic to word-building ones - turn out to conform to general normative parameters" but it is imperative "to spot bright diagnostic patches" (Nikolayeva 1991, 73).

The survey reveals that in their speech delivery, local officials as well people all over Russia tend to use short syntagmas and to make incorrect stresses (обеспеченИе, вуалировАть, углУбить), to use some substandard (jargon) words (разборка - a shoot-out, кидать - to chuck steak, крылиа - a protection racket, выбивать деньги - to beat out money, косить от армии - to dodge military service), to use quasiidiomatic structures (ближнее зарубежье - exSoviet republics, адресная помощь- targeted support, протестное голосование- protest vote, властная вертикаль - a vertical of power, административный ресурс- administrative leverage), metaphoric phrases (проиесс пошелthe process is in progress, твердая рука - a steady hand, бархатная революичия - velvet revolution).

A wide use of metaphors as means of evaluation of facts and phenomena is typical of any public speech (ветви власти- branches of power, корни реформ - roots of reforms, предвыборные баталии - election race, политическое здание - political edifice, предвыборная гонка - a race, мощный старт a strong start, шоковая терапия - shock therapy, избирательный фарс- election slapstick comedy, политический сценарий- political scenario).

The use of these widely spread words and expressions is noted by many linguists (A. Baranov, D. Dobrovolsky, Yu. Karaulov, A. Chudinov) and is treated as the "linguistic taste of the epoch" (Sternin 2008, 65).

As a rule, each candidate presents himself as a strong, honest and dignified leader:

(1) "Strength is in the truth" (A. Ivanov);

(2) "I shall be able to defend my honor as it has happened more than once... I have enough strength and abilities to serve to the city" (V. Dyakov);

(3) "I have trod a steady path slowly to my goal and tried hard to assess the readiness of people to support me; I know the municipal services and I know what to do and how to do it" (V. Bulanov).

Some of the candidates admit their disadvantages:

(4) "I do not represent the regional authorities, and I have to learn quite a lot" (V. Voroshilov).

Sometimes a candidate characterizes himself:

(5) "I have reasons to be confident that I'll manage it" (V. Pinchevich),

or characterization is made by his colleagues and companions who had helped him to become a candidate for the city manager's office: 
(6) "A guy wanted to study. He was from the poor... But he is very quick to grasp ideas, not only he can work hard but he can organize other people" (about V. Voroshilov);

(7) "A man of restless soul who makes wise decisions" (about O. Kondrashov).

Texts of campaign speeches frequently provide both self-presentation peculiarities and description of the members of the team:

(8) "Upon the whole it is a very good, efficient and professional team" (V. Zaitsev);

sometime one candidate is compared to another:

(9) "Youth and vigor versus political prudence" (V. Voroshilov vs. V. Dyakov).

It is known that Oleg Kondrashov won the election campaign having got the majority of votes. His competent campaign and masterful public speeches contributed greatly to the success.

It should be noted that Oleg Kondrashov constantly monitors both the content and the form of his speech, which is confirmed by the candidate himself: he had worked on it under the guidance of experts for a long time. In his politicking he uses standardized vocabulary that is more bookish than colloquial, which adds to his communicative image of a decisive and clever individual who realizes adequately the tasks faced by the head of the megacity.

In his public presentations, Oleg Kondrashov demonstrated his self-confidence and commitment to what he was talking about; such phraseology as "I shall do it", "We shall solve it", "It will be elaborated" is most frequent in his speeches. It helps develop an image of a person who has been engaged in the solution of the city's problems for a long time. The topics included problems of the municipal services, energy tariffs, preservation of the historical image of the city and the related problem of prohibition of modern constructions in the downtown.

The speech portrait of Vitaly Zaitsev was the closest to that of the winner: he gave brief, profound and business-like answers to the questions asked. It is believed that Vitaly Zaitsev could have won the race should Valery Shantsev, Governor of the Nizhny Novgorod region, not provide powerful support to Oleg Kondrashov.

Vladimir Bulanov's and Vladimir Dyakov's speeches are remarkable for the use of colloquial and jargon expressions, the fact is being explained by the politicians' intention to make the information comprehensible by the audience and to transit from formal to informal style of communication, i.e. to look like "one of the boys".

The survey shows that syntactical impersonal forms such as "it must be done", "it should be found", "it is necessary to use" prevail in the candidates' speeches. The predominant use of impersonal forms might mean that something must be really done to improve the city infrastructure. On the other hand, it might imply an intention to relieve oneself of the responsibility, to prompt other people to act, and reveals a lack of confidence in the victory.

At the same time such pronouns as "we" and "you" are very scarce in the candidates' speeches. It means that the candidates are not ready to conduct a political dialogue and are not willing to build political coalitions within the social group. It is revealing that Oleg Kondrashov has not invited any of his political opponents to manage the municipal services.

The survey also shows that during the election campaign all members of the social 
group use two types of speech strategies, namely, fascination and attraction, to obtain the best results.

Fascination implies such kind of influence upon people that minimizes the information losses. To master this technique, one is supposed to possess eloquence, to be skilled in speech impromptu, and be proficient in both constructive and destructive criticism.

Attraction implies a visually recorded emotional state of a person in the form of hearty feeling to another person and readiness to communicate with him/her. Spontaneity is the most typical feature of the state. Attraction can be caused by empathy, fluidic radiation, charm, affinity, etc. (Davydova 2006, 97)

In modern rhetoric both fascination and attraction play an important role in creating a communicative image. A politician wants his audience to be fascinated by his public speech and, thus, be attracted to him. The same is true about attraction. In direct interaction, a person's ability to generate psychic energy is very significant. The best means to multiply psychic energy is to strain the will. "Experts argue that points of psychic energy can magnetize the environment, send Phlegethon to it and in this way destroy its opposition. The attraction effect is an integral part of self-presentation technique. To cause this effect, it is not sufficient to have communicative skills and self-control, and to be reflexive. One is supposed to have the ability of fluidic radiation. Fluidic radiation is a dower, and not all people have it. Fluidic radiation does exit and is recorded visually through the particular brightness of eyes, peculiar intonation, attractiveness of manners and dynamism of gestures. Besides, one can exert personal influence that is not recorded but still is felt. As a rule, these features are typical of charismatic personalities." (Davydova 2006, 101)
In this regard, the most bright and attractive public presentations that accounted for all nuances of the political speech architectonics are those of O. Kondrashov, V. Zaitsev, V. Dyakov and A. Ivanov. They managed to implement two important principles in their presentations:

1) to be effective (i.e. to realize their intentions);

2) to be able to adapt to the situation.

\section{Conclusion}

To conclude, I shall note that speech of a modern political leader portraits him as a man of vast experience, a head of a large company, a good economic executive who is able to lead the way and is a charismatic personality.

A speech portrait of a modern politician should contain the following components:

1. Free speech sounding.

2. Rich intonation.

3. Individual tune.

4. Good articulation.

5. Content-richness and substantiation.

6. Persuasiveness.

7. Emotional interaction.

8. Relevance of speech.

9. Diversity of language means.

10. Unambiguousness.

11. Standardized clichés.

12. Diversity of gestures mimics and motions.

Thus, it is a priority in modern linguistics to investigate speech portraits of participants of an election campaign at the municipal level. The political elite of any city or town is a large social group that plays an important role in the life of any city or region. When parameters of an adequate speech portrait for each politician are determined, it can help make predictions of a victory or defeat in the race. Therefore, attention should be paid to the communicative behavior of person who runs for office in high places. 


\section{References}

Aristov, S.A., Susov I.P. Communicative-cognitive Linguistics and Spoken Discourse [Kommunikativnokognitivnaya lingvistika i razgovornyj diskurs]. Linguistic Bulletin, 1, 1999, pp. 3-15.

Baranov, A.N. Political Discourse: Farewell to Ritual [Politicheskij diskurs: prostchaniye s ritualom]. Chelovek (Human), 6, 1997, pp. 108-118.

Borisova, Ye.G. Distinctive Features of Types of Political Discourse in Russia [Osobennosti tipov politicheskogo diskursa v Rossii]. Politicheskij diskurs v Rossii - 2 (Political Discourse in Russia 2). Moscow: Dialog - MGU, 1998, pp. 17-18.

Borisova, Ye.G. Opposition discourse in Russia: Political Pamphlets 1989-91. Political Discourse in Transition in Europe 1989-91. Amsterdam; Philadelphia: John Benjamins Publishing Company, 1998, pp. 111-130.

Chilton, P.A. Politics and Language. The Encyclopedia of Language and Linguistics. Oxford, New York: Pergamon Press, 1994, pp. 3214-3221.

Dalton, R.J., Klingemann H.-D. Oxford Handbook of Political Behavior. Oxford: Oxford University Press, 2007.

Davydova, T.Yu. Communicative Strategies Used for Making a Political Image [Kommunikativnye strategii, ispol'zuemye pri formirovanii politicheskogo imidzha]. Moscow State University Bulletin. Political Sciences, 3, 2006, pp. 96-106.

Dementieva, M.K. Linguistic Means of Evaluation Expression in Current Russian Official Political Discourse [Yazykovye sredstva vyrazheniya otsenki v sovremennom rossijskom ofitsial'nom politicheskom diskurse]. Politicheskaya lingvistica (Political Linguistics), 30, 2009, pp. 82-92.

Nikolayeva T.M. Sociolinguistic Portrait and Methods of Its Description [Sotsiolingvisticheskij portret i metody ego opisaniya]. Russkij yazyk i sovremennost': problemy i perspektivy razvitiya russistiki (Russian Language and the Present Time. Problems and Perspectives of advance in the Russian Philology), 2. Moscow: Institut yazykoznaniya Akademii Nauk SSSR (Institute of Linguistics, the Academy of Sciences of the USSR), 1991, pp. 73-75.

Soper, P.L. Osnovy iskusstva rechi [Basic Public Speaking]. Rostov-on-Don: Phoenix, 1995.

Sternin, I.A. Prakticheskaya ritorika [Practical Rhetoric]. Moscow: Akademia, 2008.

Susov, I.P. Communicative-pragmatic Linguistics and Its Units [Kommunikativnopragmaticheskaya lingvistika i eyo yedinitsy]. Pragmatika $i$ semantika sintaksicheskich yedinits (Pragmatics and Semantics of Syntactical Units). Kalinin: KGU, 1984, pp. 3-12.

Tarasenko, T.P. Yazykovaya lichnost' starsheklassnika $v$ aspekte eyo rechevych realizatsij [Linguistic Personality of Senior High School Students from the Viewpoint of Its Realization]. Krasnodar: KGU, 2007.

Vorobieva, O.I. Politicheskiy yazyk: semantika, taksonomiya, funktsii [Political Language: Semantics, Taxonomy, Functions]. Moscow: RUDN, 2000.

Wierzbicka, A. Anti-totalitarian Language in Poland: Mechanisms of Language Self-defence [Antitotalitarnyj yazyk v Polshe: mekhanismy yazykovoj samooborony]. Voprosy yazykoznaniya (Issues of Linguistics), 4, 1993, pp. 107-125.

Wodak, R., Sedlak M. "We demand that foreigners adapt to our lifestyle": Political discourse on immigration laws in Austria and the United Kingdom. Combating Racial Discrimination: Affirmative Action as a Model for Europe. Oxford: Berg, 2000, pp. 217-237. 


\title{
Речевые стратегии и приемы \\ самопрезентации кандидатов \\ на должность главы городской администрации \\ (на материале предвыборной кампании 2010 года \\ в Нижнем Новгороде, Россия)
}

\author{
Р.А. Иванова \\ Национальный исследовательский университет \\ Высшая школа экономики \\ Россия, 603155, Нижний Новгород, \\ ул. Большая Печерская, 25/12
}

\begin{abstract}
Статья посвящена исследованию речевого портрета регионального политического деятеля. Автор устанавливает речевые характеристики, свойственные, с одной стороны, популярным и известным политическим деятелям, а с другой-малоизвестным, начинающим политикам. Исследование показывает, что кандидаты стремятся представить себя как наиболее приемлемого кандидата на выборную должность, используя при этом определенный набор языковых средств и речевых конструкиий. Как свидетельствует языковой анализ предвыборных выступлений, кандидаты используют два взаимоисключающих вида презентации себя и своих оппонентов: позитивный и негативный. Положительные характеристики формируются с помощью нейтральных прилагательных, в ряде случаев имеющих дополнительные коннотации положительного и негативного свойства; негативные черты нередко отражают особенности поведения представителей животного мира.
\end{abstract}

Ключевые слова: политический дискурс, речевой портрет, коммуникативный имидж политика, речевые стратегии, приемы самопрезентации.

Научная специальность: 10.00.00 - филологические науки. 